А. Ф. Линенко // Педагогіка і психологія. - 1995. - № 1. - С. 125-132. 6. Педагогіка вищої школи : [навч. посібник] / [3. Н. Курлянд, Р. І. Хмелюк, А. В. Семенова та ін.] ; за ред. 3. Н. Курлянд. - [3-є вид., перероб. і доп.]. - К. : Знання, 2007. - 495 с. 7. Перець О. Б. Підготовка майбутніх учителів природничо-математичних дисциплін до педагогічного проектування засобами інформаційних технологій: дис. ... канд. пед. наук: 13.00.04 / Перець Ольга Борисівна. - Одеса, 2010. - 300 с.

УДК 37: 33 -057: 159.923: $811 \ll 71 »$

Олена Семеног, Андрій Семеног

\title{
СУЧАСНИЙ ЕКОНОМІСТ ЯК ПРОФЕСІЙНА МОВНА ОСОБИСТІСТЬ: УСПІХИ І ПРОБЛЕМИ СТАНОВЛЕННЯ В УМОВАХ ВИЩОЇ ЕКОНОМІЧНОЇ ШКОЛИ
}

Семеног О. М., Семеног А. Ю. Сучасний економіст як професійна мовна особистість: успіхи і проблеми становлення в умовах вищої економічної школи.

У статті розглядаються окремі аспекти вияву мовної, термінологічної, комунікативно-прагматичної, текстової, дискурсивної компетенцій мовної особистості фахівця економічної сфери. Окреслюється вплив особистісних рис економіста як наставника на формування мовної особистості студента - майбутнього економіста.

Ключові слова: економіст, професійний економічний текст, мовна особистість, мовна, термінологічна, комунікативно-прагматична, текстова, дискурсивна компетенції.

Семеног Е. Н., Семеног А. Ю. Современный экономист как профессиональная языковая личность: успехи и проблемы становления в условиях высшей экономической школы.

Статья посвящена рассмотрению отдельных аспектов проявления языковой, терминологической, коммуникативно-прагматической, текстовой, дискурсивной компетенций языковой личности специалиста экономической сферы. Охарактеризовано влияние личности экономиста как наставника на формирование языковой личности студента - будущего экономиста.

Ключевые слова: экономист, профессиональный экономический текст, языковая личность, языковая, терминологическая, коммуникативно-прагматическая, текстовая, дискурсивная компетенции.

Semenog O. N., Semenog A. Y. Modern economist as a professional linguistic personality: success and challenges of formation in Higher Economics School.

The report is devoted to the certain aspects of language, terminology, communicative, textual, discursive competence of the person skilled in economic sphere. The presentation describes the influence of the individual of economist on the formation of the linguistic identity of the student - the future economist.

Key words: economist, professional linguistic text, linguistic personality, the language, terminology, communicative, textual, discursive competence.

Вимоги роботодавців зактуалізовують такі професійно важливі якості економістів, як творчий та аналітичний стиль мислення, емоційна стабільність і самовладання, здатність генерувати нове розв' язання нестандартних виробничих ситуацій і практичних задач, усвідомлення культурних зразків професії. Визначальними в досягненні фахового успіху є вміння аргументовано будувати усне і писемне професійно-ділове спілкування, інтерпретувати готовий і створювати власний професійний економічний текст, a їх 
високий рівень свідчить про максимальне прагнення до неперервного професійного розвитку, саморозвитку і самореалізації, до фахової майстерності.

Отже, в умовах трансформації економічної моделі в Україні, зміни змісту і стилю економічного розвитку країни, інтеграції вітчизняної економіки у світовий економічний простір виникає необхідність здійснити аналіз професійної мовної особистості сучасного економіста. У межах статті охарактеризуємо окремі аспекти вияву мовної, термінологічної, комунікативно-прагматичної, текстової, дискурсивної компетенцій мовної особистості фахівця економічної сфери, означимо успіхи i проблеми становлення професійної мовної особистості в умовах вищої економічної школи, вплив особистісних рис економіста як наставника на формування мовної особистості економіста-початківця.

Теоретичною основою дослідження слугують роботи, у яких обгрунтовано специфіку мовної особистості (Н. Голуб, Ю. Караулов, Г. Богін, Н. Карпухіна, Л. Мацько, О. Селіванова, Л. Струганець); специфіку тексту (Н. Валгіна, В. Чернявська), дискурсу (Ф. Бацевич), формування професійного мовлення фахівців економічного профілю ( В. Гордієнко, С. Хоцкіна, І. Ярощук). Джерельною базою для прикладів професійного мовлення слугують монографії і статті викладачів, докторів економічних наук, професорів Української академії банківської справи $[3 ; 6 ; 7 ; 8 ; 13]$.

Аналіз професійних економічних текстів і професійного економічного мовлення переконує у відповідності структури мовної особистості економіста цілісній структурі мовної особистості, яку запропонував Ю. Караулов [4]. Російський науковець, зокрема, виокремлює три рівні володіння мовою. Вербально-семантичний рівень, або внугрішній лексикон особистості, представлений у мовній свідомості у вигляді мікросистем (лексикосемантичних груп, граматичних засобів, словосполучень і речень). Лінгвокогнітивний рівень представлений тезаурусом особистості. Його одиницями є поняття, слова-символи (концепти), фрази, які виформовуються в кожного економіста як мовної індивідуальності в більш або менш упорядковану й систематизовану мовну картину світу.

Для економіста важливим є третій, прагматичний рівень, або рівень діяльніснокомунікативних потреб, що визначається пізнавальною діяльністю, інтелектуальною сферою, зумовлюється специфікою економічного дискурсу в соціально-прагматичному руслі. Вершина цього рівня - створення власного ідіостилю (економіст готує контракти, пише економічні звіти, наукові статті, виступає з повідомленнями і доповідями тощо). У реальності межі між цими рівнями досить нетривкі, розпливчасті, а структурні компоненти - лексикон, тезаурус, прагматикон визначають етапи формування мовної особистості. Формування прагматичного рівня мовної особистості, розвиток інтелекту, творчих здібностей, свободи мислення відбувається впродовж усього життя.

Для розвитку економіста як мовної особистості вагому роль відіграє широкий економічний світогляд, економічна компетенція, основою формування якої слугують знання не лише 3 мікро- та макроекономіки, біржі, організації та управління підприємствами, проведення аудиту та ведення обліку фінансової документації, а й 3 історії, української та зарубіжної літератури, іноземної i, безумовно, рідної, української мови. В основу фінансової поведінки покладено мовленнєву поведінку, що має відповідати нормам соціально-професійної взаємодії [1] і передбачає володіння уміннями налагоджувати контакт зі співрозмовниками, виявляти професійний підхід до розв'язання поставлених комунікативних завдань. Значною мірою ці вимоги забезпечуються відповідним рівнем мовної компетенції.

Як показує аналіз економічних наукових статей, лекцій, відеозаписів наукових форумів, пріоритетне місце у професійному мовленні фахівців економічної галузі займають лексичні одиниці мовної системи: економічна термінологія вузького i 
широкого вжитку, професіоналізми, соціально маркована лексика, економічний (біржовий) жаргон. 3-поміж часто вживаних переважають, на жаль, не питомі українські слова або словосполучення (попит, гроші, безстроковий вклад, господарський розрахунок, угода, управління тощо), а численні запозичення з англійської (банкнота, лізинг, бізнес, брокер, дилер, менеджмент), французької (абандон, аванс, акциз, баланс, пролонгація), німецької (бухгалтер, біржа, маклер, рента), італійської (банк, банкрут, брутто, валюта, кредит,), польської (достаток, рахунок, кошти) мов. Іноді економічні тексти суцільно (до 90 відсотків) перемежовані запозиченнями.

Інтенсивний прихід лексичних запозичень в економічну сферу діяльності фахівці пояснюють зовнішніми і внутрішніми чинниками. Серед зовнішніх чинників називають активні економічні контакти між українцями та іншими народами і поширення західного досвіду; появу нових галузей економічної діяльності (маркетинг, менеджмент); авторитетність мови-джерела. Сьогодні такою перевагою володіє англійська мова. Н. Попова на достатній вибірці показує зростання кількості англіцизмів за тематичною групою «Економіка, банківська справа і фінанси» впродовж 30-тих XX ст. - початку XXI ст.: у 30-і pp. XX ст. їх налічувалося 4\%; у 70-80-і pp. XX ст. $7 \%$, у 90-і pp. ХХ ст. -2000 р. - 21,5\%, упродовж 2000 - 2003 рр. кількість зросла до 26 \% [9]. 3-поміж номінацій цієї групи 50 відсотків займають поняття, що стосуються економічної та банківсько-фінансової діяльності (мерчандайзинг, стайлінг, крос-курс, демаркетинг); 20 відсотків - назви предметів, ділових паперів, контрактів (ф'ючерс, бонд, екю); 16 відсотків - назви осіб, залучених до економічної та банківсько-фінансової діяльності (дисконт-брокер, бренд-менеджер, джобер, трейдер, дилер, дистриб'ютор); 14 відсотків - назви закладів та приміщень у цій галузі (факторкомпанія, офшор, бізнес-хол).

Внутрішньолінгвістичними причинами динамічного проникнення лексичних запозичень у професійне мовлення сучасних економістів уважають номінативну необхідність. Визначимо, зокрема, відсутність у рідній мові відповідного слова і його потребу для називання нового предмета, нового явища, поняття (наприклад, маркетинг від англ. market означає широку діяльність у сфері ринку товарів, послуг, цінних паперів); необхідність розмежовувати змістовно близькі, але все ж різні поняття (дилерторговець); економію мовних засобів; тенденцію до заміни словосполучень й описових зворотів однослівними найменуваннями (саміт-зустріч на найвищому рівні; банківський білет - банкнота; приватизачійний чек-ваучер).

При всій повазі до іншомовної культури все частіше і самі фахівці економічної сфери виступають за екологію професійного мовлення. У своїх наукових працях, оперуючи фінансовою термінологією, прагнуть хоча б спорадично застосовувати i синонімічні українські відповідники до запозичень. Наприклад, поряд зі словом кліринг функціонують і такі відповідники отримання, звірка інформації, поряд зі словом котирування - відповідник встановлення курсу, поряд зі словом маржа - відповідник різничя ичін. Запозичення преференція заміняють на слова пільги, переваги, сальдо - на відповідник залишок, хеджування - на відповідник зменшення ризику, ф ючерс- на відповідник угода на майбутнє, дивіденд- на відповідник прибуток, економія - на відповідник ощзадливість, компенсація - на відповідник відшкодування; дисконтний на відповідник обліковий. Звичайно, якщо іноземне слово має додаткові смислові відтінки, яких в українській мові немає, доцільніше вживати запозичений термін.

Вищий рівень мовної культури спостерігаємо тоді, коли фахівець економіки намагається подати відповідний за граматико-стилістичним змістом вислів українською мовою. Звернімо увагу на терміни і терміносполуки, які викликали труднощі 3 перекладом у викладачів i студентів Української академії банківської справи: 
курировать - опікуватися; выпускаемая продукция - продукція, щуо випускається; привлекаемье инвестиции - залучені інвестииіі; приобретаемые средства - споживчі кочти; безналичный расчет - безготівковий розрахунок, действующее законодательство - чинне законодавство. Уникнути таких недоліків можна, постійно звертаючись до словників професійного (економічного) спрямування.

Особливе місце в економічному мовленні займає жаргон, за допомогою якого характеризують рух цін, стан попиту і пропозиції на біржі, а також уживають для визначення котирувань. Наприклад, бик - це брокер, який грає на підвищення; ведмідь біржовий спекулянт, що грає на пониження; динамітник - дилер, який продає ненадійні цінні папери; кішки і собаки - вищого ступеня спекулятивні і зазвичай низько оцінювані ринком фондові цінності, за якими дивіденди не виплачуються; магазин - дилерська компанія, що продовжує операції з купівлі-продажу облігацій; сміття - цінні папери низького рівня ліквідності, бовтанка - незаконна спроба брокера зібрати для собі додаткові суми комісії шляхом прискореної купівлі-продажу цінних паперів за вказівками клієнтів [4; 10].

Жаргонна лексика «сприяє» появі нових найменувань, що лексично і семантично пов'язані між собою. Наприклад: наліт ведмедів - це активний продаж «без покриття», що здійснюється задля зниження рівня цін, щоб вигідно купити товар; тиск на «ведмедів»- заходи, що офіційно вживаються центральними банками для того, щоб на валютній біржі зробити вплив на спекулянтів, які грають на пониження цін «без покриття»; ринок ведмедів - ринок, на якому діє тенденція падіння цін.

Професійне мовлення економіста часто вирізняється «соковитими» фразеологізмами, в основу яких покладено марковане слово. В обігу фахівців Сумської універсальної біржі (інформацію надала кандидат педагогічних наук В. Гордієнко), зокрема, часто вживаними є такі стійкі словосполучення: відкупити маржу (означає наказ клієнта брокерові купити найближчий за терміном ф'ючерсний контракт і продати контракт на більш віддалений термін); обідрана облігація (означає облігація з окремим відсотковим купоном, який може бути вилучений 3 метою погашення або для самостійної купівлі-продажу); копчений оселедець (означає попередній проспект, що в загальних рисах інформує про емісію облігаційної позики).

У професійних текстах [13] виокремл.ємо також фразеологічні звороти, основу яких складають терміни. Наприклад, термін ринок слугує основою таких стійких словосполучень: важжий ринок - положення на ринку, при якому число наказів продати перевищує число доручень купити; закритий ринок- стан ринку, коли курс покупця рівний курсу продавця; ледачий (млявий, невпевнений) ринок-ринок, на якому практично відсутня торгівля; відсутня реальна пропозиція купити або продати, можливості встановити реальний рівень цін; міцний (спокійний, стійкий) ринок - стан високих цін на ринку із тенденцією до зростання; ринок биків- ринок, на якому діє тенденція до зростання цін, натомість ринок ведмедів - ринок, на якому діє тенденція до падіння цін.

Окремі фразеологічні звороти становлять собою цілісний термін, широко вжитий у професійному колі економістів. Зокрема, у професійній діяльності брокерів, маклерів, дилерів вагому роль відіграє біржова гра. Так називають спекулятивні операції на біржі задля отримання прибутку завдяки прогнозуванню динаміки котирувань біржових товарів, фондових цінностей, а також за рахунок різниці котирувань і курсів на різних біржах. Біржова гра, в основі якої емоції, приречена на провал.

Результатом успішної мовленнєвої діяльності економіста $є$ професійний текст (ділові папери, звіти, наукові статті, монографії, виступи, експертні висновки, промови). При своїй типовості кожний економічний текст індивідуальний. Це залежить від автора, його ерудиції, досвіду текстотворення, прагнення до самовираження (це знаходить вияв 
в авторських прийомах застосування різних мовних засобів). Науковий текст має зумовити якісну зміну (розширення, поглиблення) загальної картини світу як автора продукту, так і споживача.

Для створення наукового тексту важливі, переконує Н. Валгіна [2], прагматична установка тексту (визначається його типом, жанром, завданнями) і прагматична установка автора, що знаходить вияв в авторській модальності. Аналіз наукових текстів засвідчує, що ці прагматичні установки можуть суміщатися, а можуть і суперечити одна одній. Отже, є необхідність у саморозвитку текстової, жанрової компетенції мовної особистості економіста.

У межах дослідження зупинимося на наукових публікаціях викладачів Української академії банківської справи. Для наукових текстів О. Костюка характерні цілісність, логічна зв'язність, членованість, послідовність, точність наукової термінології, вірогідність вихідної інформації, критичність у відборі фактів і доказовість. Прикметна риса наукових текстів С. Козьменка $\epsilon$ їх прозорість і чіткість. Наукові тексти, автором яких $є$ I. Школьник, чітко відображають проблему дослідження; автор логічно висуває гіпотези, орієнтує читачів на нове знання, характеризується доцільністю й раціональністю усіх положень, орієнтований на досягнення дослідницької мети і завдань. Дотримується і принципу інтертекстуальності, діалогічності, повідомляючи про мету дослідження (зупинимося на), кваліфікуючи свої дії (розглянемо, проілюструємо, наведемо приклад), висловлюючи власне бачення аналізованої проблеми і дискутуючи з читачами [13].

Високої результативності досягають фінансові установи, працівники яких здійснюють ефективну комунікативну взаємодію 3 колегами, партнерами чи замовниками, уміють аргументовано обгрунтувати варіанти розв'язання економічних проблем, урегулювати складні професійні ситуації, розробити стратегії розвитку підприємства. Значною мірою це залежить від набутої дискурсивної компетенції, що відображає здатність мовної особистості будувати і сприймати цілісні дискурси різних типів (усні та писемні) відповідно до комунікативного наміру в межах певної професійної ситуації спілкування з урахуванням специфіки їх семантико-прагматичної та граматичної організації на макро- і мікрорівні та взаємозв'язку екстралінгвістичних і лінгвістичних компонентів [14]. Ф. Бацевич характеризує професійну комунікативну ситуацію як певні умови спілкування за участі комунікантів, що спонукають їх до міжособистісної інтеракції. Вона «визначає мовленнєву поведінку, способи реалізації комунікативної інтенції (стратегію, тактику комунікації тощо)» [1].

Важливими комунікативними ознаками професійного мовлення $є$ змістовність, точність, логічність, правильність, стислість викладу думок, доказовість, коректність та доречність уживання термінів, насиченість інформацією, чистота мови, виразність дикції, милозвучність. Такою усною мовленнєвою культурою добре володіли українські економісти М. Балудянський, М. Бунге, I. Франко, які в XIX ст. активно працювали в галузі класичної економічної теорії. Зокрема, Іван Франко у двадцять вісім років успішно виступив 3 доповіддю про статистику як метод і як науку, яку й нині вважають класичною. Кожне слово досвідченого письменника й економіста випромінювало потужну інтелектуальну та емотивну енергію. Успіх письменника і економіста був зрозумілий. У Франкову добу в Галичині турбувалися про людей, які добре володіли мовленим словом. О.Сербенська [11] пише про різноманітні форми публічного спілкування - сходини, гутірки, засідання, збори, академії, на яких фахівці виступали 3 промовами, рефератами, лекціями, відчитами, проводили диспути.

Наші сучасники продовжують і вдосконалюють набуті традиції. Окреслимо лекції викладачів економічних дисциплін Української академії банківської справи. Представником елітарного типу вважають відомого науковця-економіста О.Костюка 3 
його скромністю, відкритістю наукових позицій, щирою, яскраво вираженою повагою до численних учнів, високою загальною й економічною культурою, ерудованістю (О. Костюк - учасник Всесвітньої Економічної Асоціації в Німеччині, дійсний член Швейцарської асоціації банківської справи та фінансів), досвідом лекторської діяльності за кордоном (О. Костюк $є$ професором Магістерської програми 3 корпоративного управління Шведської школи економіки та бізнес-адміністрування (м. Гельсинки, Фінляндія).

Професор С. Козьменко включає у свої лекції елементи короткого діалогу 3 аудиторією, ставить кілька мініпроблем і вимагає самостійних дій студентів, спрямованих на розв'язання проблем. Науковий діалог із професором Т. Васильєвою спонукає до розвитку умінь висловити власну думку в гармонії форми і змісту. Свої лекції науковець готує 3 дотриманням основних принципів англійського філософа-лінгвіста Пола Грайса: кількість інформації («Не говорити більше чи менше, ніж потрібно для виконання поточних цілей діалогу»); якість («Не говорити того, що вважаєш хибним або для чого не маєш достатніх підстав»); спосіб («Уникай неоднозначності, будь лаконічним і організованим»); «комунікативна співпраця», що виявляється в коректності висловленої критики й етичному оформленні негативної оцінки.

На лекціях професора І. Школьник ми обов'язково стаємо свідками, як народжується i пульсує наукова думка. Посилення аргументації, - зауважує дослідниця, - обгрунтування положень, переконання повинні йти паралельно за двома напрямами: раціональним та емоційним. Серед прийомів, що активізують діяльність студентів, лектор пропонує прийоми співучасті, навіювання (апелювання до спільності професійних, соціальних інтересів), текстового очікування (подається спочатку факт, а відтак його пояснення), прийом проблематизації знань (формулювання на початку лекції проблемного запитання і пошук відповіді на нього впродовж заняття спільно зі слухачами). Науковець доводить: насамперед через інтерес та інтелектуальні відчуття важливо досягати активного сприйняття й осмислення основного змісту.

Толерантність наукової дискусії на лекціях відомих економістів зумовлює дотримання шанобливого ставлення до думки іншого, критичний підхід не тільки до чужих, а й до власних наукових результатів, орієнтацію на некатегоричність викладу. Важливий і принцип «комунікативної співпраці», що виявляється в коректності висловленої критики й етичному оформленні негативної оцінки, яку за науковим етикетом слід пом'якшувати. Емоційна взаємодія, що грунтується на співтворчості, i набуті знання втіляться у нових дослідженнях, науковому пошуку студентів, допоможе майбутнім економістам формувати власний ідостиль, манеру спілкування.

Отже, мовна особистість сучасного економіста - це так звана саморегулююча система, що перебуває під впливом різноманітних соціальних і економічних змін $\mathrm{i}$ чинників, мовної моди в галузі економічного спілкування, формується у певному соціокультурному просторі, відповідному ментальному середовищі, значною мірою зумовлюється світоглядом. Професійне мовлення під кутом зору теорії мовної особистості є сукупністю одиниць різних рівнів мовної системи (у дослідженні увага передусім зверталася на лексичний рівень).

Показниками загальнокультурної, мовної, термінологічної компетенції економіста $€$ глибокі знання особливостей економічної термінології, теорії і практики мовленнєвого впливу, уважне ставлення до питомої лексики і фахових термінів. Цьому сприяє постійне читання зарубіжної і вітчизняної наукової економічної літератури, довідників, вивчення економічного досвіду. Сформованість мовної особистості економістапочатківця залежить від фундаментальної, мовної підготовки, прикладу і впливу особистісних рис економіста-наставника. Мовний розвиток сучасного економіста 
значною мірою залежить від державної підтримки, однак насамперед від власного прагнення до саморозвитку і самореалізації.

1. Бацевич Ф. С. Основи комунікативної лінгвістики : [підручник]/ Ф. С. Бацевич. - К. : Академія, 2004. - 344 с. 2. Валгина Н. С. Теория текста: [учебн. пособие]/ Н. С. Валгина. - М. : Логос. 2003. - 280 с. - Режим доступу 5.06.2012: http://www.evatist.ru/text14/ 01.htm. - Загол. 3 екрану. - Мова рос. 3. Васильсва Т. А. Діяльність банківських установ на ринку інноваційного інвестування: методологічні засади : дис. ... доктора економ. наук : спец. 08.00.08- «Гроші, фінанси і кредит» [Текст]/ Т. А. Васильєва; ДВНЗ «УАБС НБУ».- Суми. - 2008. - 504 с. 4. Караулов Ю. Н. Русский язык и языковая личность / Ю. Н. Караулов. - М. : ЛКИ, УРСС Эдиториал, 2010. - 264 с. 5. Карпухина Н. М. Лексико-семантические процессы в русской терминологии товарно-денежного обращения : автореф. дис. на соискание науч. степени канд. філол. наук: 10.02 .01 /Н. М. Карпухина; Московский гос. област. унт. - М., 2007. - 34 с. 6. Козьменко О. В. Страховий ринок України у контексті сталого розвитку : [монографія]/ О. В. Козьменко. - Суми : ДВНЗ «УАБС НБУ», 2008. - 352 с. 7. Козьменко С. М. Розвиток методичних підходів до формалізації структури вітчизняного фінансового ринку/ С. М. Козьменко, С. В. Лєонов // Вісник Університету банківської справи Національного банку України. - 2010. - № 2. - С. 3-9. 8. Лєонов С. В. Інвестиційний потенціал банківської системи України [Текст]: монографія / С. В. Лєонов. - Суми : ДВНЗ «УАБС НБУ», 2009. - 375 с. 9. Попова Н. О. Структурносемантичні особливості новітніх лексичних запозичень 3 англійської в українську мову (90-і pp. XX ст. - початок XXI ст.) : автореф. дис.на здобуття наук.ступеня канд. філол. наук: $10.02 .01 /$ Н. О. Попова; Запоріз. держ. ун-т. - Запоріжжя, 2005. - 19 с. 10. Семеног О. Українська мова : професійне спрямування - біржова діяльність : практикум : [навч. посіб. для студ. біржових спец. вищ. навч. закл.] / Олена Семеног, Валентина Гордієнко - К. : Бії Граф, 2007. - 220 с. 11. Сербенська О. Мовлене слово у життєсвіті Івана Франка. [Електронний ресурс] - Режим доступу: http://journ.Inu.edu.ua/publications/zbirnyk07/Zbirnyk07_ Serbenskhtm. 12. Словник іншомовних слів / за ред. О. С. Мельничука. - К., 1975. - 776 с. 13. Школьник І. О. Фінансовий ринок України: сучасний стан та стратегія розвитку: [монографія]/ I. О. Школьник. - Суми : Мрія, УАБС НБУ, 2008. - 348 с. 14. Ярощук І. Діловий дискурс фахівця економічного профілю як комунікативне явище [Електронний ресурс]Режим доступу: journal.mandrivets.com/images/file/Jaroshchuk_2012_3.pdf.

Тетяна Філатьєва

\section{АНАЛІЗ РЕЗУЛЬТАТІВ ДОСЛІДНО-ЕКСПЕРИМЕНТАЛЬНОЇ РОБОТИ З ПІДГОТОВКИ МАЙБУТНІХ ФАХІВЦІВ У ГАЛУЗІ МИСТЕЦТВА ДО ХУДОЖНЬО-ПЕДАГОГІЧНОЇ ДІЯЛЬНОСТІ В ПОЗАШКІЛЬНИХ ЗАКЛАДАХ ОСВІТИ}

Філатьєва Т. В. Аналіз результатів дослідно-експериментальної роботи 3 підготовки майбутніх фахівців у галузі мистецтва до художньо-педагогічної діяльності в позашкільних закладах освіти.

У статті підсумовуються результати дослідно-експериментальної роботи, яка проводилась у вищих художньо-педагогічних навчальних закладах. Авторка визначає 